\title{
Mitigating Cadmium (Cd) Toxicity in Montane Forest Soils Using Biochar: Laboratory Trial for Soils from Horton Plains, Sri Lanka
}

\author{
Ranmalee Bandara1 (), Priyantha Indralal Yapa², Rasanjali de Silva², Kasun Lakmini'2,3, \\ Niluka Ranasinghe ${ }^{3}$, Mahina Senevirathne ${ }^{4}$ \\ ${ }^{1}$ Faculty of Geomatics, Sabaragamuwa University of Sri Lanka, Belihuloya, Sri Lanka \\ ${ }^{2}$ Faculty of Agricultural Sciences, Sabaragamuwa University of Sri Lanka, Belihuloya, Sri Lanka \\ ${ }^{3}$ Faculty of Graduate Studies, Sabaragamuwa University of Sri Lanka, Belihuloya, Sri Lanka \\ ${ }^{4}$ Faculty of Applied Sciences, Sabaragamuwa University of Sri Lanka, Belihuloya, Sri Lanka \\ Email: ranmalee@geo.sab.ac.lk
}

How to cite this paper: Bandara, R., Yapa, P.I., de Silva, R., Lakmini, K., Ranasinghe, N. and Senevirathne, M. (2021) Mitigating Cadmium (Cd) Toxicity in Montane Forest Soils Using Biochar: Laboratory Trial for Soils from Horton Plains, Sri Lanka. Open Journal of Soil Science, 11, 504-520. https://doi.org/10.4236/ojss.2021.1110025

Received: September 19, 2021

Accepted: October 23, 2021

Published: October 26, 2021

Copyright $\odot 2021$ by author(s) and Scientific Research Publishing Inc. This work is licensed under the Creative Commons Attribution International License (CC BY 4.0).

http://creativecommons.org/licenses/by/4.0/ (c) (i) Open Access

\begin{abstract}
Horton Plains (HP), one of the two montane forests in Sri Lanka and habitat to many endemic species of plants and animals, has been severely affected by forest dieback. Past research has identified a direct link between soil pollution with Cadmium (Cd) and the phenomenon of forest dieback. As a consequence, forest dieback is increasing proportionately to the soil pollution. Hence, this study focuses on identifying a cost-effective remediation technique to neutralize soil $\mathrm{Cd}$, and thereby reducing forest dieback. Soil samples were collected from HP, mainly Thotupolakanda site which shows more than $90 \%$ severity of forest die back, and bulked together. The soil was high (13.4) in organic matter and low (5.42) in $\mathrm{pH}$, and three soil amendments were tested in this research as; bio char prepared using 1) rubber nut shells, 2) rice husk, and 3) dead wood from HP. Each sample was spiked with $20 \mathrm{ml}$ of 5 ppm (parts per million) Cd solution, and four treatments a) soil + rubber-nut shell biochar (T1), b) soil + rice husk biochar (T2), c) soil + wood-from-HP biochar (T3), and d) soil only (T4), with five (05) replicates, were setup. During the first eight weeks after the application of treatments, it was observed that $\mathrm{T} 1$ showed the best performance, by showing a consistent trend in reducing the available soil Cd, with $\mathrm{T} 2$ following closely. The interesting observation was that the natural forest soil (T4) was also able to buffer the loading of Cd. At the close of the experiment, it was observed that the available soil Cd goes almost to zero, in less than 24 months.
\end{abstract}

\section{Keywords}

Forest Dieback, Soil Amendments, Cadmium, Biochar, Natural Geosorbents 


\section{Introduction}

Skeletons of dead and dying large trees have become a common feature of most of the area in Horton Plains (HP), Sri Lanka. Untimely death of trees and large scale destruction of the natural montane forest vegetation appears to have brought a massive destruction to this important natural resource. Multiple tree death in this montane forest, where the trees normally lose their foliage from top to bottom, without showing any clear sign of a physical disturbance, insect attack, orfungal disease-i.e. Forest dieback in the HP, was first observed in Thotupolakanda and reported by Perera [1]. Ranasinghe et al. [2] and Chandrajith and Dissanayake [3] have precisely identified two of the key causes for the destructive forest die-back in $\mathrm{HP}-$ i.e. Cadmium $(\mathrm{Cd})$ and Lead $(\mathrm{Pb})$ in the forest soil. Through the interference with respiration and other crucial metabolic functions of the forest vegetation, death is inflicted to the plants by these toxic heavy metals [4]. Of the many heavy metals, $\mathrm{Cd}$ is one of the most mobile, and is therefore highly bio-available, and yet, the mobility is controlled by soil characteristics like $\mathrm{pH}$, texture, and the organic matter content [5]. The accumulation of $\mathrm{Cd}$ and $\mathrm{Pb}$ in the soil at toxic levels is mostly due to anthropogenic activities like agricultural, mining and industrial activities. As a result, a number of countries have come up with national norms regarding the permitted levels of various toxic elements in the soil matrix. Levels of concentration, depending on the soil $\mathrm{pH}$, are termed as: 1) Reference level, 2) Research level, and 3) Priority intervention level. The reference level for agricultural soils is $90 \%$ of the heavy metal concentration of natural, non-polluted soils. This is also the highest value permitted for non-polluted soils. The research level must be applied to anything above this level, and when a soil is considered to be polluted, the potential toxicity should be determined after subjecting it to various determinations, which are chemical in nature, as biological evaluations have not been recommended. The highest level of toxicity, the intervention level, indicates levels that are considered dangerous to soil, which needs priority remediation [6].

A major factor of the dynamic soil quality (soil health) is determined by natural soil microbes, whose activities will be degraded through the toxicity of these two metals. Additionally to this, the overall quality of the water is determined by the health of the soil. HP is much more than a natural forest. It is the most important water catchment in the island of Sri Lanka, feeding three (03) major rivers-Mahaweli, Walawe, Kelani [7]. As such, there is an urgent need to find a practical and sustainable method to contain, and then cleanse the heavy metal contamination of soils. The reason behind this is, elements like $\mathrm{Cd}$ and $\mathrm{Pb}$ are considered to be nonessential metals to plants, on the contrary, toxic [8] [9] to plants, thereby negatively impacting the soil health, and consequently degrading the quality of the water in Sri Lanka linked to the catchment of HP. Under the classification, HP is an Upper Montane forest, and upper montane vegetation overreacts even to minor changes in the environment [10]. Thus, healthy existence of this precious resource will be crucial for the sustenance of the bio-diversity, 
water supply, agriculture, food security and the livelihood of the majority of the population in Sri Lanka. Additionally, HP is a significant tourist attraction that generates an immense income to the country's economy. HP is also a special natural habitat for some extremely rare species of flora and fauna.

One of the isolated key contaminants, $\mathrm{Cd}$, can neither be destroyed nor removed via ordinary chemical or biological remediation techniques. Therefore, the only option left will be to utilize an in-situ method to effectively immobilize these elements. Through this, the movement and the impact of this contaminant within the forest eco-system could be successfully restricted. Provided that the right immobilizing agent-i.e. geo-sorbent-is used, the detoxification will be permanent. Since the HP is a protected, extra-sensitive natural eco-system, the remediation techniques to be introduced must not interfere with natural functioning of the system, and as such, the use of a natural geo-sorbent, such as biochar, is one of the best options.

The thermal degradation of organic materials without oxygen, or with minimal concentration of oxygen (pyrolysis) results in a solid product, "char". It is coined as "biochar" when utilized as a soil amendment to improve fertility and sequester carbon (C) [11]. Per the temperature that is selected during the pyrolysis process, and with the feedstock type, the amount of existing carbon in biochar will vary [12] [13]. For example, the net $\mathrm{C}$ mineralization and $\mathrm{N}_{2} \mathrm{O}$ emissions from sandy and silt-clay soils amended with poultry litter biochar at $400^{\circ} \mathrm{C}$ were significantly greater than when compared with biochar from swine manure [14]. One of the major characteristics shown by biochar is its' high stability against decay, while the other is having a higher ability to retain nutrients when compared to other forms of soil organic matter. Hence, biochar is ideal for use as a soil amendment, benefitting the environment in different ways such as; 1) mitigation of climate change, 2) improvement of soils, and 3) reduction of environmental pollution [11]. However, the stability of any biochar depends on many factors, for example, nature of the reactions between the biochar and soil constituents like dissolved organic and inorganic matter, microbes, and plant roots.

A number of studies have demonstrated the high capacity of biochar to adsorb pollutants in soils [15] [16] [17] [18]. A major factor contributing to the sorption of contaminants is the physical structure of the biochar. This is because the surface area increases by some thousand-fold during the pyrolysis process, when compared to the original material. This in turn provides a large number of sites for sorption [16] [17]. Using carbon containing materials such as activated carbon, black carbon, and biochars for mitigating metal toxicity via trapping, and as a soil conditioner to facilitate plant performance is increasing, due to their high surface area and reactivity. When it comes to carbon sequestrating and soil conditioning, black carbon, biochar, and other conventional charcoals show many similarities. Yet, in most cases, they would act differently when used for adsorbing heavy metals. Based on the pyrolysis parameters such as the oxygen content 
and combustion temperature, and the sources of biomass used for biochar production, the sorption capacities will show significant differences [19].

$\mathrm{Cd}$, which is non-essential to plants, is recognized as a metal contaminant. Therefore, it can also be considered as a major environmental concern as its prevailing time in soil is more than a thousand years [20]. Several changes to the biochemistry, physiology, and structure of plants in the soil-plant relationship can be observed due to the presence of Cd. Additionally, Cd toxicity could result from disturbance in plant metabolism, as a consequence of disturbance in the uptake and translocation of mineral nutrients [21]. Researchers have also shown that $\mathrm{Cd}$ toxicity can reduce both photosynthesis and the mineral nutrition in plants [22] [23] [24]. Additionally, observations have shown that Cd induces oxidative stress in plants via increasing the production of reactive oxygen species [25], which could potentially damage the biological macromolecules and create chaos in the antioxidant system in plants.

Researchers have worked on investigating the efficacy of using biochar to immobilize the heavy metal Cd in soil [26]-[31]. For example, in a heavily contaminated soil with biochar added to it, an $87 \%$ uptake of the heavy metal Cd, in comparison to the Cd uptake of the barley that grew in the same soil with no biochar, was observed. This further revealed that the plants' uptake of heavy metals was substantially reduced in soil which contained $2 \%$ biochar [32]. The capacity of immobilizing $\mathrm{Cd}^{2+}$ ions from a heavy metal contaminated soil in Sri Lanka (Entisols) mixed with coconut shell biochar have been shown to be above $80 \%$ [31]. The chemical constituents of biochar reveals the presence of myriads of active sites, which could form strong bonding with positively or negatively charged toxic metal ions [33]. Additionally, the sorption capacity of metals decreases increasing acidity [34] [35] [36].

Biochar has tightly packed aromatic structures, for enabling it to exist for longer periods of time without getting degraded by microbes, as shown in anthrosol soils in which biochar was applied as a soil remediating agent [37] [38]. The older the biochar, the higher its efficiency is, to immobilize heavy metals and metaloids. This is because oxidation of biochar continues through aging, results a higher number of carboxyl groups. It means that the total minus charge increases, leading to an increase in cation exchange capacity [39]. Consequently, the persistent impact of biochar on immobilizing toxic metals depends on its existence in soil, and there is also an increment in charge with time. Metal trapping efficiency of biochar is affected by the variations in soil reactions that influence the $\mathrm{pH}$ induced ionic nature [40], the pyrolysis temperature, and raw materials that impact the availability of active groups that generate metal complexes [41]. Additionally, neutralization of toxic metals is linked with the amount of minerals in the related ash in most biochar products (e.g. phosphate) [42], and through the variations in the surface area and porous nature of biochar [43]. These characteristics are determined through the raw material used, the pyrolysis temperature, and the production conditions such as residence time and heat- 
ing rate [44] [45]. The effectiveness of specific biochar materials also depends on soil properties [46], the particular heavy metals of interest [47], and the variations between plant species with their nature of root growth, and their capabilities to adsorb and store heavy metals [48].

However, the use of biochar as an in-situ remedial measure for montane forests with severe dieback is yet to be investigated in detail. As such, this study is a preliminary laboratory trial to assess the efficacy of using biochar as a cleanser for forest soils contaminated with $\mathrm{Cd}$.

\section{Materials and Methods}

\subsection{Study Area}

The soil samples for the experiment were collected from Horton Plains, Sri Lanka (as shown in Figure 1), an identical tropical montane forest between the altitudes of 1500 and $2524 \mathrm{~m}$ above MSL [49]. Geographical location of Horton Plains is about $32 \mathrm{~km}$ south of Nuwara Eliya in the Central Highlands of Central Province, with latitudes between $6^{\circ} 47 " \mathrm{~N}$ and $6^{\circ} 50 " \mathrm{~N}$, and longitudes between $80^{\circ} 46^{\prime \prime} \mathrm{E}$ and $80^{\circ} 50^{\prime \prime} \mathrm{E}[50]$.

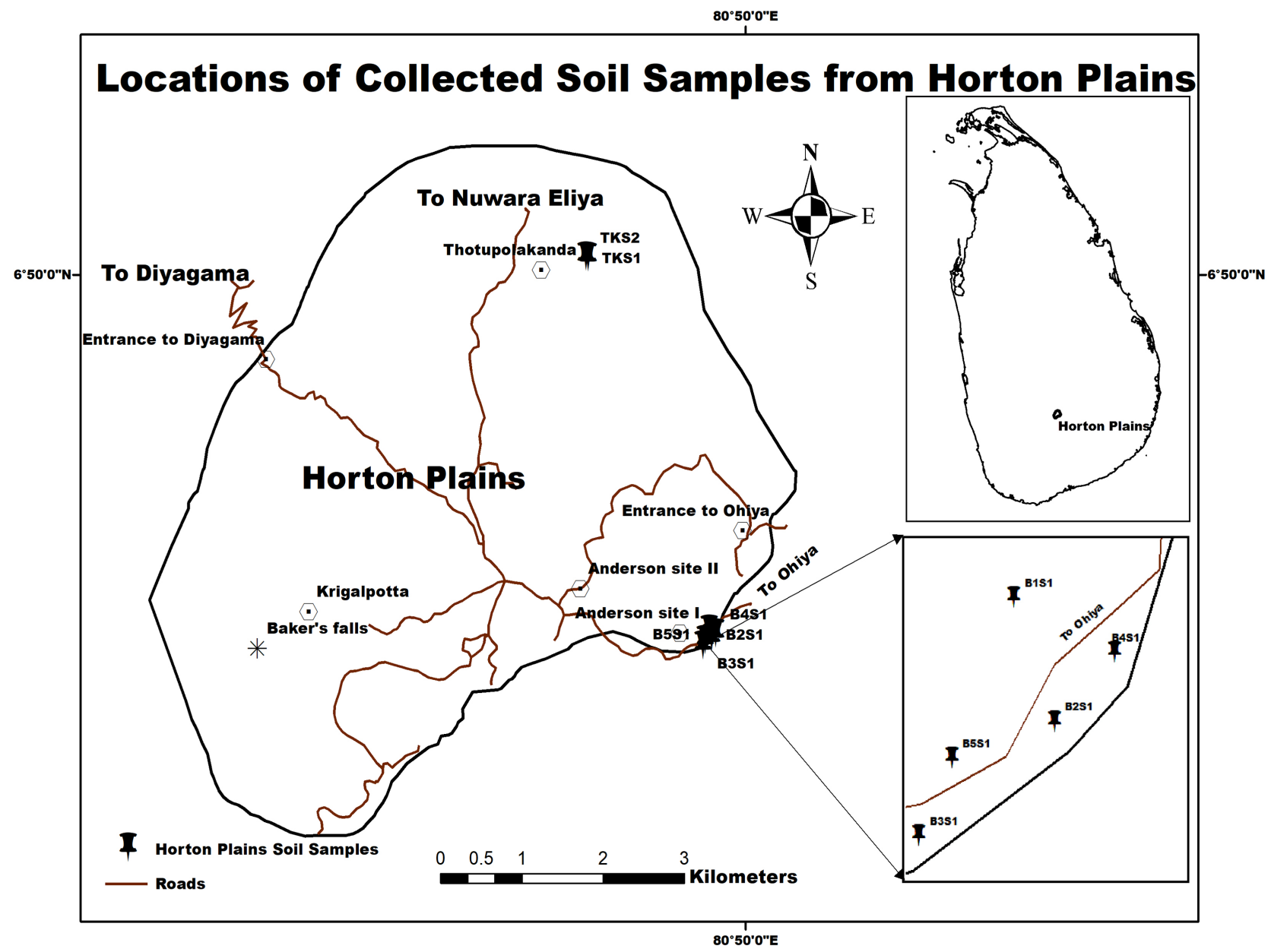

Figure 1. Locations of soil samples used in the bulking process, in Horton Plains, Sri Lanka. 


\subsection{Methodology}

\subsubsection{Characteristic Analysis of Soil and Biochar}

The homogenized soil sample for the laboratory trial was prepared by bulking all soils collected from HP. The soil was ground using a mortar and pestle, then sieved through a nylon sieve to $2 \mathrm{~mm}$ and air dried at $30^{\circ} \mathrm{C}$. The resulting dried $2 \mathrm{~mm}$ sieved soil was used for the laboratory studies. A portion of this sample was used to measure basic soil physical characteristics for $\mathrm{pH}\left(\mathrm{H}_{2} \mathrm{O}\right)$ [51], texture [52], EC (Electrical Conductivity) [53] and SOM (Soil Organic Matter) [54] using standard analytical procedures. Extractable $\mathrm{Cd}$ was determined by batch methods using the following reagents: 1) de-mineralised water, 2) $0.01 \mathrm{M} \mathrm{CaCl}_{2}$ [55], 3) $0.05 \mathrm{M} \mathrm{CaCl}_{2}$ [56], 4) IN Ammonium acetate-acetic acid solution buffered at $\mathrm{pH} 7.0$ [57], and 5) $0.05 \mathrm{M} \mathrm{Na}_{2}$ EDTA [57]. The initial moisture factor of the samples was also measured.

\subsubsection{Experimental Setup}

Biochar was prepared using three (03) types of raw materials; 1) rubber-nut shell, 2) rice husk, and 3) dead wood from $\mathrm{HP}$, under $400^{\circ} \mathrm{C}-500^{\circ} \mathrm{C}$ pyrolysis temperature. The $\mathrm{pH}, \mathrm{EC}$, and available $\mathrm{Cd}$ concentration were measured for all biochar.

From the bulked sample, twenty (20) separate samples each weighing $25 \mathrm{~g}$, were prepared. Addition of biochar to the soil was $5 \%$ by weight. Each sample was then spiked with $20 \mathrm{ml}$ of $5 \mathrm{ppm}$ (parts per million) Cd solution. Four (04) treatments 1) soil + rubber-nut shell biochar (T1), 2) soil + rice husk biochar (T2), 3) soil + wood-from-HP biochar (T3), and 4) soil only (T4), with five (05) replicates, were setup in accordance with the Complete Randomized Design (CRD) (SAS Institute Inc., 2012).

The prepared soil samples were initially incubated for two (02) weeks, and a soil extraction was taken as follows. $4 \mathrm{~g}$ of soil was measured into conical flasks and $10 \mathrm{ml}$ of $1 \mathrm{M} \mathrm{NH}_{4} \mathrm{NO}_{3}$ solution was added into each flask, and sealed with para films.

These were then placed on a shaker and shaken for 3 hours at $180 \mathrm{rpm}$. Afterwards, all solutions were double filtered through Whatmann No.1 filter papers into test tubes. These samples were analyzed for available Cd concentration using the AAS.

\section{Results and Discussion}

General characteristics of soil in the study area (Table 1) indicate that the soil is strongly acidic [58] and the soil organic matter (SOM) level, 13.2\% is high [59].

Organic matter is a key to soil quality, linked with the ecological importance of the soil, which determines ecosystem productivity, affecting climate quality. The critical limit for organic matter in farm soil is $2 \%$ by weight, below which the sustainability of soil quality cannot be maintained. The critical limit of organic matter for forest soils is yet to be assessed. Organic matter content of normal forest soils varies between $1 \%-5 \%$ by weight [59]. Obviously, the cation 
Table 1. General characteristics of the soil sample from HP, Sri Lanka.

\begin{tabular}{cc}
\hline Soil texture & Sandy Loam \\
\hline $\mathrm{pH}$ & 5.42 \\
Soil Organic Matter (SOM) & 13.4 \\
Electrical Conductivity (EC) & $4260 \mu \mathrm{S} / \mathrm{cm}$ \\
Cation Exchange Capacity (CEC) & $210 \mathrm{cmol} / \mathrm{kg}$ of soil \\
\hline
\end{tabular}

exchange capacity (CEC), $210 \mathrm{cmol} / \mathrm{kg}$ of soil, is very high due to the richness of the soil with SOM. Electrical conductivity of $4260 \mu \mathrm{S} / \mathrm{cm}$ indicates that the soil is slightly saline [60]. Low $\mathrm{pH}$ in HP soils is linked with the presence of organic acids with low pKa-values, which are released into the soil solution during the organic matter degradation and by root secretions [61]. Perhaps, the vegetation and litter fall are sources of acidity in soils in HP [62]. Additionally, the area of HP receives a very high rainfall exceeding $3500 \mathrm{~mm} / \mathrm{year}$, which is acidic in general, as a result of the formation of carbonic acid from carbon dioxide in the air.

This weak acid results in the $\mathrm{pH}$ of the rain to stay 5.0 - 5.5. If the acidity of rain water goes below normal levels, it results in speedy acidification of soil, and when the annual precipitation exceeds $800 \mathrm{~mm}$, the soil $\mathrm{pH}$ usually remains acidic [63]. Washing out of alkaline cations (e.g., $\mathrm{Na}^{+}, \mathrm{K}^{+}, \mathrm{Ca}^{2+}$, and $\mathrm{Mg}^{2+}$ ) present in the soil profile increases soil acidity [64], and severe leaching losses can be expected in HP with the amount of usual rainfall in the area.

A dramatic decline of available form of $\mathrm{Cd}$ was observed during the first three weeks after spiking the soil with $\mathrm{Cd}$ (as shown in Figure 2) in all the treatments including control-i.e., Cd sorption in the soils has continued roughly until the end of the third week from spiking. If observed closely, it can be seen that T1 showed the best performance, by showing a consistent trend in reducing the available soil Cd, with $\mathrm{T} 2$ following closely.

One reason for this could be that the rubber-nut shell is high in lignin [65]. Biochar made from heavily lignified materials has been found to be effective in immobilizing heavy metals [66]. The decline of available soil $\mathrm{Cd}$ in control indicates that soil itself has a limited but significant capacity to sorb soluble or plant available form of $\mathrm{Cd}$ in the soil. However, further studies are needed to understand the extent of the buffering capacity of the soil. But it is helpful to keep in mind that under natural conditions, there is only so much that the soil can safeguard, before the equilibrium snaps and give rise to various issues like forest dieback.

$\mathrm{Cd}$ that enters to the soil through different mechanisms is subjected to a myriad of reactions such getting adsorbed on to soil colloids, precipitation, and combining with chemical substances in soil solutions, and consequent adsorption of such combinations to soil fragments. Cd adsorption in soils can be categorized into 1) nonspecific sorption, 2) specific sorption, 3) inorganic or organic ligand mediated sorption, and 4) precipitation or co-precipitation. Under 


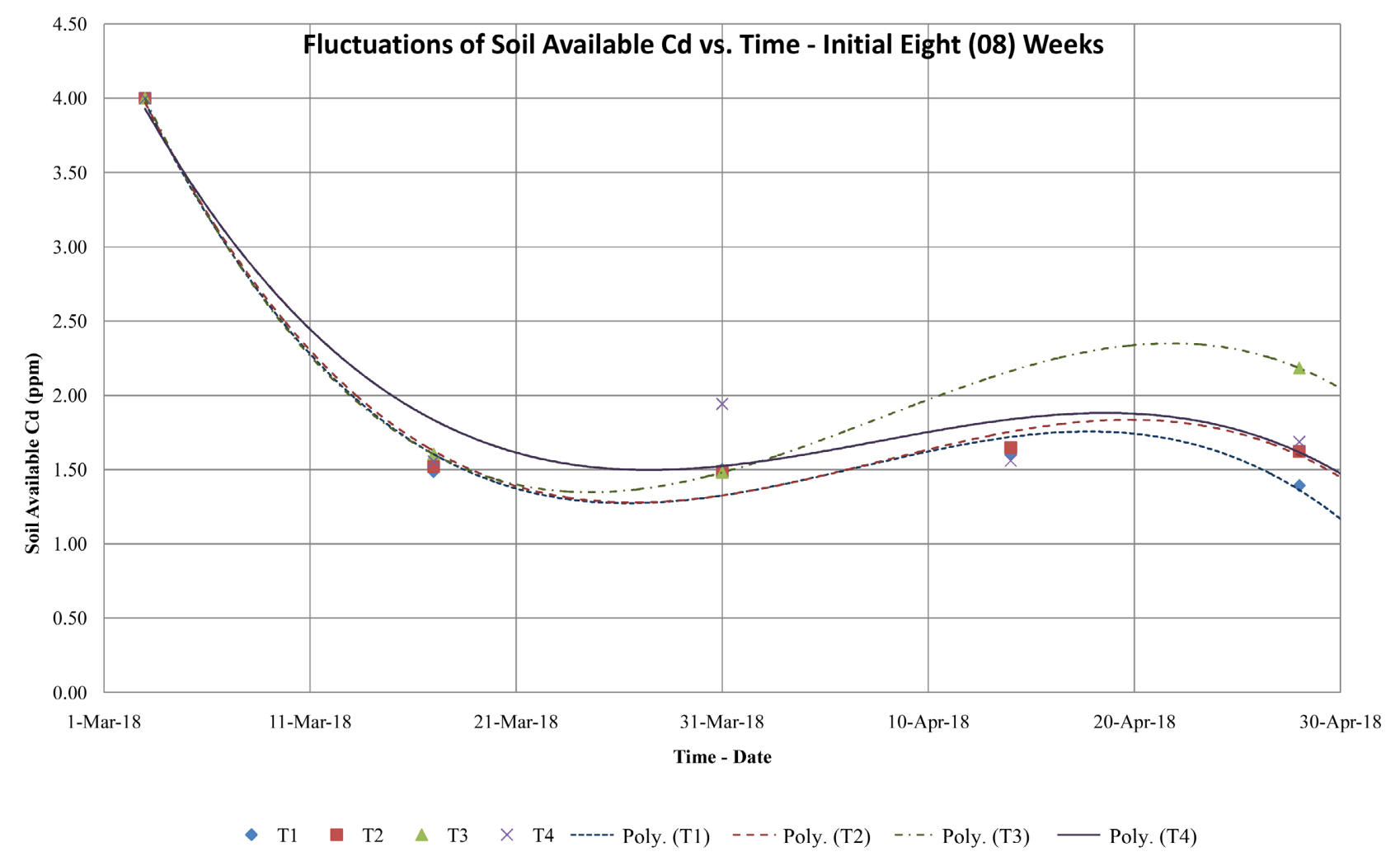

Figure 2. Fluctuations of soil available Cd (in ppm) during the initial 8 weeks after spiking. The four treatments are; 1$)$ soil + rubber-nut shell biochar (T1), 2) soil + rice husk biochar (T2), 3) soil + wood-from-HP biochar (T3), and 4) soil only (T4).

nonselective adsorption, Cd stays on negatively charged sites on soil colloids via electrostatic bonding. The adsorbed $\mathrm{Cd}$ is then assumed to be completely hydrated [67], and can be found in the diffuse double layer as outer sphere surface complexes [68]. The Cd adsorbed nonspecifically is subjected to exchanging ions with different cations present in the soil solution, and is hence assumed as available. This Cd shows vulnerability to be washed out, and exist in a form toxic to biological organisms. The adsorbed Cd is considered to be partially hydrated, and freely exchangable with other adsorbing ions like Zn. For these reasons, presumably, the observed desorption after the third week is a result of other ions which tend to exchange sorbed $\mathrm{Cd}$.

Depending on the constituents of the soil, there are different sites for $\mathrm{Cd}$ sorption. $\mathrm{Cd}$ is adsorbed electrostatistically on the $\mathrm{pH}$-independent negatively charged sites in the 1:1 and 2:1 layer silicate minerals, and particularly on differently charged sites on alumina faces and aluminol edges [69] [70]. Soil organic matter adsorbs $\mathrm{Cd}$ at the negatively charged carboxylic and phenolic groups or directly with these and other active groups, forming monodentate or multidentate bonding. Cd adsorption in soils is impacted by both the solution and solid phases [71].

Soil reaction, or $\mathrm{pH}$, is one of the prominent factors affecting $\mathrm{Cd}$ adsorption in soils [72] [73]. Cd adsorption goes up with $\mathrm{pH}$, mimicking a sigmoid-type pattern. It means that the soil acidity in the study area should promote the de- 
sorption of Cd to result in an increased toxicity on plants.

However, the addition of biochar may counter the influence of soil acidity on increased desorption by two ways-i.e., neutralizing soil $\mathrm{pH}$, and providing adsorption sites.

To obtain an understanding of the behavior of $\mathrm{Cd}$ sorption by the natural geosorbents, a 3rd order polynomial function was fitted to the observations during the first eight weeks of adding the treatments to the soil samples, as shown in Table 2.

The immobilization technique used in this study was treating the soil with natural geosorbants - they were biochar produced from different raw materials, expecting the stabilization of mobilized or plant available forms of $\mathrm{Cd}$ in the soil, given that the main focus was to reduce Cd mobility and toxicity in soils. It appears that all the biochar types have been effective in immobilizing soil Cd. Biochar has become popular across the world as a remediating agent to neutralize toxic heavy metals in soil and water.

Most biochars are alkaline in nature, and add $\mathrm{P}, \mathrm{K}$, and $\mathrm{Ca}$ in available forms, which contribute to heavy metal immobilization in soil. It has been proven that the concentrations of $\mathrm{Cd}$ and $\mathrm{Zn}$ in the leachate can be reduced by 300 - and 45-fold, respectively, by the addition of biochar [17]. An important method to retain of $\mathrm{Cd}$ and other toxic metallic elements by biochars is the sorption. Application of only $5 \%$ to the soil, biochar has provento be capable of immobilizing 30 - 94 of the available forms of Cd [74].

However, the interactions between different species of ions in contaminated soils may results mobilization of some immobilized ions after the addition of biochar. For example, mobilization of $\mathrm{As}$ and $\mathrm{Cu}$ has been observed in an experiment after amending the soil with wood biochar [75]. Immobilizing amendments used may have altered the original metal form-i.e. toxic fractions for biological organisms to non-toxic, immobilized forms such as immobilized metallic elements or precipitates, via the joint methods of adsorption, complexation, and precipitation. However, T4, the control, also has shown some potential for cleaning itself through the immobilization of soil $\mathrm{Cd}$. The soil is extraordinarily rich with organic matter (13.4\%). Soil organic matter (SOM) contains humic substances (humic acids, fulvic acids and humins), and of these, both humic

Table 2. Best-fit 3rd order polynomial equation-initial 8 weeks after spiking-fluctuation in available soil $\mathrm{Cd}$ with the addition of natural geosorbents.

\begin{tabular}{cccc}
\hline $\begin{array}{c}\text { Treatment } \\
\text { ID }\end{array}$ & $\begin{array}{c}\text { Treatment } \\
\text { Name }\end{array}$ & Best-fit Equation & $\begin{array}{c}\text { Correlation } \\
\text { coefficient }\left(\mathrm{R}^{2}\right)\end{array}$ \\
\hline T1 & $\begin{array}{c}\text { Rubber Nut } \\
\text { Shell }\end{array}$ & $-9 \mathrm{E}-05 \mathrm{x}^{3}+11.175 \mathrm{x}^{2}-482725 \mathrm{x}+7 \mathrm{E}+09$ & 0.9881 \\
T2 & Rice Husk & $-8 \mathrm{E}-05 \mathrm{x}^{3}+10.368 \mathrm{x}^{2}-447892 \mathrm{x}+6 \mathrm{E}+09$ & 0.9893 \\
T3 & HP wood & $-9 \mathrm{E}-05 \mathrm{x}^{3}+11.551 \mathrm{x}^{2}-498975 \mathrm{x}+7 \mathrm{E}+09$ & 1.0000 \\
T4 & Control & $-7 \mathrm{E}-05 \mathrm{x}^{3}+9.1344 \mathrm{x}^{2}-394582 \mathrm{x}+6 \mathrm{E}+09$ & 0.9224 \\
\hline
\end{tabular}


acids, fulvic acids also are effective metal immobilizing agents. Organic soil amendments have been widely used to immobilize heavy metals in contaminated environments. Humic and fulvic acids change speciation of metal ions from readily available forms for biological organisms to more-or-less stable and less toxic fractions linked to SOM, metal oxides, or carbonates [76]. Very specifically, the humic acids can make bonds with a range of heavy metals and metaloids such as $\mathrm{Cd}, \mathrm{Cr}, \mathrm{Cu}$, and $\mathrm{Pb}$ [76] [77].

Due to various national and university-level interruptions and constraints, the researchers were unable to measure the available $\mathrm{Cd}$ concentration in the soil samples continuously. As such, the next round of samples was measured after a hiatus of 19 months.

It is observed from Figure 3 that the soil available $\mathrm{Cd}$ (in ppm) is very close to zero, with the maximum concentration at $0.01 \mathrm{ppm}$.

A $3^{\text {rd }}$ order polynomial was fitted (as shown in Table 3 ) to the observations

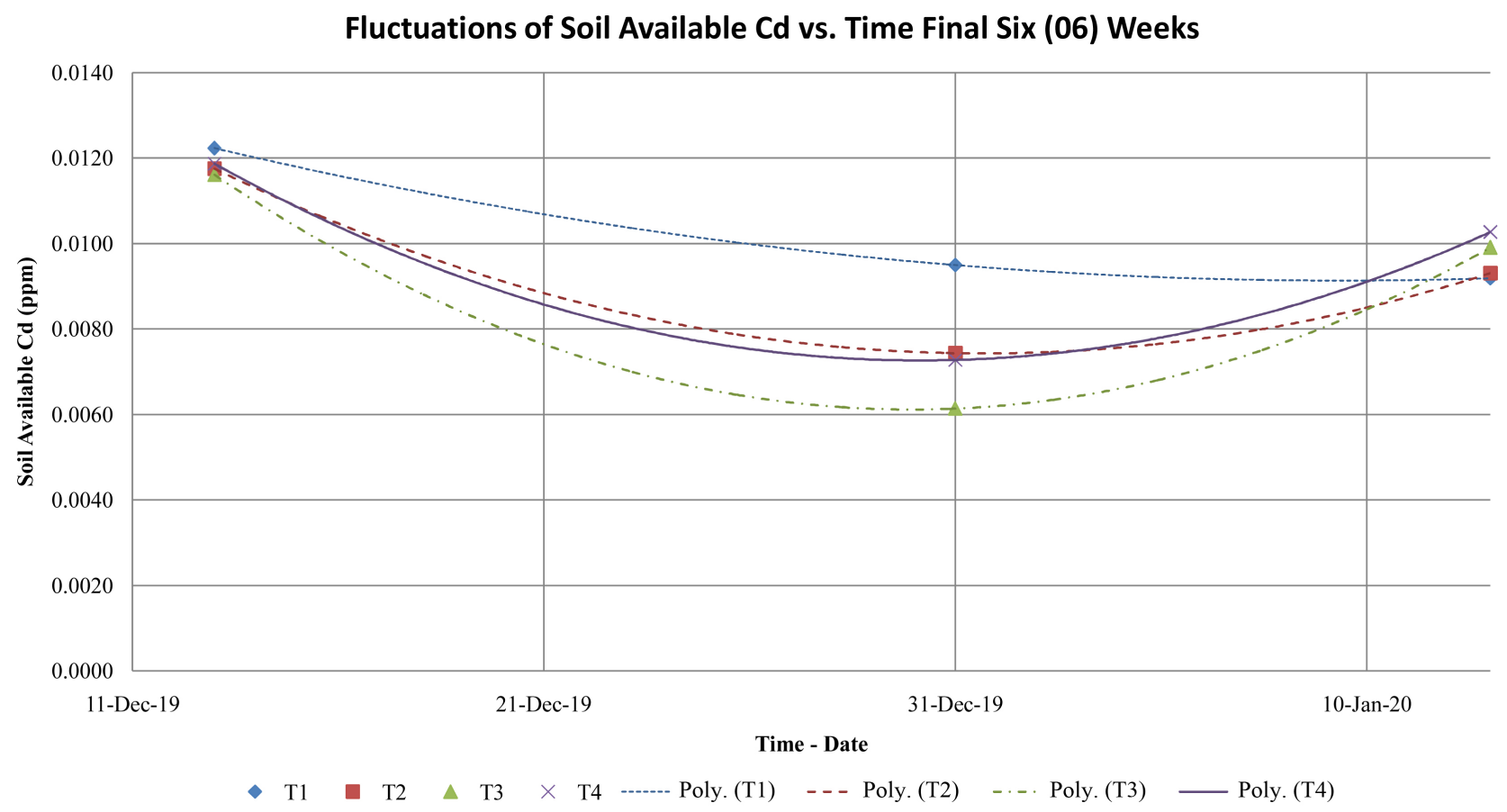

Figure 3. Fluctuations of soil available Cd (in ppm) during the final six weeks after spiking. The four treatments are; 1) soil + rubber-nut shell biochar (T1), 2) soil + rice husk biochar (T2), 3) soil + wood-from-HP biochar (T3), and 4) soil only (T4).

Table 3. Best-fit 3rd order polynomial equation—final 6 weeks after spiking—fluctuation in available soil Cd with the addition of natural geosorbents.

\begin{tabular}{cccc}
\hline Treatment ID & Treatment Name & Best-fit Equation & Correlation coefficient $\left(\mathrm{R}^{2}\right)$ \\
\hline T1 & Rubber Nut Shell & $4 \mathrm{E}-06 \mathrm{x}^{2}-0.3624 \mathrm{x}+7942.9$ & 1 \\
T2 & Rice Husk & $1 \mathrm{E}-05 \mathrm{x}^{2}-1.0852 \mathrm{x}+23783$ & 1 \\
T3 & HP wood & $2 \mathrm{E}-05 \mathrm{x}^{2}-1.6786 \mathrm{x}+36785$ & 1 \\
T4 & Control & $2 \mathrm{E}-05 \mathrm{x}^{2}-1.3724 \mathrm{x}+30076$ & 1 \\
\hline
\end{tabular}


for better understanding and prediction of the behavior of the soil available $\mathrm{Cd}$ after 18 months of application. The long-term behavior of biochar in a contaminated soil was observed to have come to equilibrium, close to zero availability.

\section{Conclusions}

The study in general, has focused on assessing the capacity of natural geosorbants in reducing the bioavailability of soil $\mathrm{Cd}$. It has been observed that the bioavailability goes down, almost to zero, in less than 24 months. Nevertheless, certain key characteristics must be considered when choosing a matching geosorbant for any practical use. The bond between the detoxifying material, the specific metal, and the dominant soil characteristics, should be considered first because, it will principally decide both the detoxifying efficiency and the environmental impacts throughout. Then, before the application of geosorbant in the field, the cost-effectiveness should be evaluated to estimate the general affordability of the techniques. At the same time, natural residue cleansing agents are usually comparatively more cost effective than synthetic agents. Cost is a major contributing factor to the implementation of these natural agents as cleansers, together with detoxifying efficacy of the material. As the principal objective is to use soil remediating agents to mitigate $\mathrm{Cd}$ toxicity, the use of geosorbants contaminated with harmful and unwanted elements and compounds, for example other toxic metals and metalloids, toxic organic residues, salts, and radioactive materials above the safety limits must be restricted. In other words, before using, the cleansing agents have to be analyzed for its constituents. Lastly, after using a cleansing material, constant continous observation is mandatory for understanding the detoxification efficacy, connected to other harmful and unwanted materials leaching or increasing the mobilization of toxic metals, plant nutrients, or salts.

At this time, the key limitation of this in-situ soil Cd detoxification technique is that $\mathrm{Cd}$ is not taken out from the soil and therefore, persists in the ecosystem as an oncoming threat, simply waiting for activation through unpredicted fluctuations in soil chemical and chemical properties. The challenge is to identify an affordable and practical amendment technique, which is ecologically safe, and is able to concurrently impact multiple contaminants in the long-term. Identifying cost-effective and ecologically sound soil detoxifying agents to fulfill the need for correcting the soil contamination issues in forests and agro-ecosystems in particular, is a timely requirement.

\section{Acknowledgements}

We wish to thank the Department of Wildlife Conservation for granting permission to collect soil and foliar samples from Horton Plains, Sri Lanka, and the Park Ranger and all officers of Horton Plains for their generous assistance during data collection. 


\section{Funding Statement}

This work was supported by the Sabaragamuwa University of Sri Lanka [grant number SUSL/RG/2016/04].

\section{Conflicts of Interest}

The authors declare that there is no conflict of interest regarding the publication of this article.

\section{References}

[1] Perera, W.R.H. (1978) Thotupolakanda-An Environmental Disaster? Sri Lanka Forester, 13, 53-55.

[2] Ranasinghe, P.N., Dissanayake, C.B., Samarasinghe, D.V.N. and Galappatti, R. (2007) The Relationship between Soil Geochemistry and Die Back of Montane Forests in Sri Lanka: A Case Study. Environmental Geology, 51, 1077-1088. https://doi.org/10.1007/s00254-006-0399-6

[3] Chandrajith, R. and Dissanayake, C.B. (2009) Phosphate Mineral Fertilizers, Trace Metals and Human Health. Journal of the National Science Foundation of Sri Lanka, 37, 153-165. https://doi.org/10.4038/jnsfsr.v37i3.1219

[4] Chibuike, G.U. and Obiora, S.C. (2014) Heavy Metal Polluted Soils: Effect on Plants and Bioremediation Methods. Applied and Environmental Soil Science, 2014, 12 p. https://doi.org/10.1155/2014/752708

[5] Adriano, D.C. (2001) Bioavailability of Trace Metals. In: Trace Elements in Terrestrial Environments, Springer, New York, 61-89.

https://doi.org/10.1007/978-0-387-21510-5_3

[6] Moreno, J., Bastida, F., Ros, M., Hernández, T. and García, C. (2009) Soil Organic Carbon Buffers Heavy Metal Contamination on Semiarid Soils: Effects of Different Metal Threshold Levels on Soil Microbial Activity. European Journal of Soil Biolo$g y, 45,220-228$. https://doi.org/10.1016/j.ejsobi.2009.02.004

[7] Rajapaksha, P.R.U., Nandasena, K.A., Gunawardena, E.R.N. and Rosier, P.T.W. (1996) Water Quality Parameters of Fog, Rain, Throughfall and Stream Water at Horton Plains Forestry Symposium-Sri Jayawardhanapura University, Sri Jayawardhanapura University.

[8] Lombi, E., Zhao, F.J., Dunham, S.J. and McGrath, S.P. (2001) Phytoremediation of Heavy Metal-Contaminated Soil. Journal of Environmental Quality, 30, 1919-1926. https://doi.org/10.2134/jeq2001.1919

[9] Yapa, P.I. (2015) Soil Chemical Quality and Forest Die-Back. International Journal of Environmental Science and Development, 6, 1-8. https://doi.org/10.7763/IJESD.2015.V6.551

[10] Loope, L.L. and Giambelluca, T.W. (1998) Vulnerability of Island Tropical Montane Cloud Forests to Climate Change, with Special Reference to East Maui, Hawaii. Climate Change, 39, 503-517. https://doi.org/10.1023/A:1005372118420

[11] Lehmann, J. and Joseph, S. (2009) Biochar for Environmental Management: An Introduction. Routledge, 33-46.

[12] Sun, Y., Gao, B., Yao, Y., Fang, J., Zhang, M., Zhou, Y., Chen, H. and Yang, L. (2014) Effects of Feedstock Type, Production Method, and Pyrolysis Temperature on Biochar and Hydrochar Properties. Chemical Engineering Journal, 240, 574-578. 
https://doi.org/10.1016/j.cej.2013.10.081

[13] Ronsse, F., Van Hecke, S., Dickinson, D. and Prins, W. (2013) Production and Characterization of Slow Pyrolysis Biochar: Influence of Feedstock Type and Pyrolysis Conditions. GCB Bioenergy, 5, 104-115. https://doi.org/10.1111/gcbb.12018

[14] Subedi, R., Taupe, N., Pelissetti, S., Petruzzelli, L., Bertora, C., Leahy, J.J. and Grignani, C. (2016) Greenhouse Gas Emissions and Soil Properties Following Amendment with Manure-Derived Biochars: Influence of Pyrolysis Temperature and Feedstock Type. Journal of Environmental Management, 166, 73-83. https://doi.org/10.1016/j.jenvman.2015.10.007

[15] Ma, J., Wang, H. and Luo, Q. (2007) Movement-Adsorption and Its Mechanism of $\mathrm{Cd}$ in Soil under Combining Effects of Electrokinetics and a New Type of Bamboo Charcoal. Environmental Science, 28, 1829-1834.

[16] Beesley, L., Moreno-Jiménez, E. and Gomez-Eyles, J.L. (2010) Effects of Biochar and Greenwaste Compost Amendments on Mobility, Bioavailability and Toxicity of Inorganic and Organic Contaminants in a Multi-Element Polluted Soil. Environmental Pollution, 158, 2282-2287. https://doi.org/10.1016/j.envpol.2010.02.003

[17] Beesley, L. and Marmiroli, M. (2011) The Immobilisation and Retention of Soluble Arsenic, Cadmium and Zinc by Biochar. Environmental Pollution, 159, 474-480. https://doi.org/10.1016/j.envpol.2010.10.016

[18] Debela, F., Thring, R. and Arocena, J. (2012) Immobilization of Heavy Metals by Co-Pyrolysis of Contaminated Soil with Woody Biomass. Water, Air, \& Soil Pollution, 223, 1161-1170. https://doi.org/10.1007/s11270-011-0934-2

[19] Keiluweit, M., Nico, P.S., Johnson, M.G. and Kleber, M. (2010) Dynamic Molecular Structure of Plant Biomass-Derived Black Carbon (Biochar). Environmental Science \& Technology, 44, 1247-1253. https://doi.org/10.1021/es9031419

[20] Di Toppi, L.S. and Gabbrielli, R. (1999) Response to Cadmium in Higher Plants. Environmental and Experimental Botany, 41, 105-130.

https://doi.org/10.1016/S0098-8472(98)00058-6

[21] Nazar, R., Iqbal, N., Masood, A., Khan, M.I.R., Syeed, S. and Khan, N.A. (2012) Cadmium Toxicity in Plants and Role of Mineral Nutrients in Its Alleviation. American Journal of Plant Sciences, 3, 1476-1489. https://doi.org/10.4236/ajps.2012.310178

[22] Dias, M.C., Monteiro, C., Moutinho-Pereira, J., Correia, C., Gonçalves, B. and Santos, C. (2013) Cadmium Toxicity Affects Photosynthesis and Plant Growth at Different Levels. Acta Physiologiae Plantarum, 35, 1281-1289.

https://doi.org/10.1007/s11738-012-1167-8

[23] de Araújo, R.P., de Almeida, A.-A.F., Pereira, L.S., Mangabeira, P.A., Souza, J.O., Pirovani, C.P., Ahnert, D. and Baligar, V.C. (2017) Photosynthetic, Antioxidative, Molecular and Ultrastructural Responses of Young Cacao Plants to Cd Toxicity in the Soil. Ecotoxicology and Environmental Safety, 144, 148-157. https://doi.org/10.1016/j.ecoenv.2017.06.006

[24] Rizwan, M., Ali, S., Adrees, M., Ibrahim, M., Tsang, D.C., Zia-ur-Rehman, M., Zahir, Z.A., Rinklebe, J., Tack, F.M. and Ok, Y.S. (2017) A Critical Review on Effects, Tolerance Mechanisms and Management of Cadmium in Vegetables. Chemosphere, 182, 90-105. https://doi.org/10.1016/j.chemosphere.2017.05.013

[25] Nagajyoti, P.C., Lee, K.D. and Sreekanth, T. (2010) Heavy Metals, Occurrence and Toxicity for Plants: A Review. Environmental Chemistry Letters, 8, 199-216. https://doi.org/10.1007/s10311-010-0297-8 
[26] Park, J.H., Choppala, G., Lee, S.J., Bolan, N., Chung, J.W. and Edraki, M. (2013) Comparative Sorption of $\mathrm{Pb}$ and $\mathrm{Cd}$ by Biochars and Its Implication for Metal Immobilization in Soils. Water, Air, \& Soil Pollution, 224, Article No. 1711. https://doi.org/10.1007/s11270-013-1711-1

[27] Venegas, A., Rigol, A. and Vidal, M. (2015) Viability of Organic Wastes and Biochars as Amendments for the Remediation of Heavy Metal-Contaminated Soils. Chemosphere, 119, 190-198. https://doi.org/10.1016/j.chemosphere.2014.06.009

[28] Zhang, Z., Solaiman, Z.M., Meney, K., Murphy, D.V. and Rengel, Z. (2013) Biochars Immobilize Soil Cadmium, but Do Not Improve Growth of Emergent Wetland Species Juncus subsecundus in Cadmium-Contaminated Soil. Journal of Soils and Sediments, 13, 140-151. https://doi.org/10.1007/s11368-012-0571-4

[29] Chi, T., Zuo, J. and Liu, F. (2017) Performance and Mechanism for Cadmium and Lead Adsorption from Water and Soil by Corn Straw Biochar. Frontiers of Environmental Science \& Engineering, 11, Article No. 15.

https://doi.org/10.1007/s11783-017-0921-y

[30] Trakal, L., Bingöl, D., Pohořelý, M., Hruška, M. and Komárek, M. (2014) Geochemical and Spectroscopic Investigations of $\mathrm{Cd}$ and $\mathrm{Pb}$ Sorption Mechanisms on Contrasting Biochars: Engineering Implications. Bioresource Technology, 171, 442-451.

https://doi.org/10.1016/j.biortech.2014.08.108

[31] Paranavithana, G., Kawamoto, K., Inoue, Y., Saito, T., Vithanage, M., Kalpage, C. and Herath, G. (2016) Adsorption of $\mathrm{Cd}^{2+}$ and $\mathrm{Pb}^{2+}$ onto Coconut Shell Biochar and Biochar-Mixed Soil. Environmental Earth Sciences, 75, Article No. 484. https://doi.org/10.1007/s12665-015-5167-Z

[32] Lehmann, J., Rillig, M.C., Thies, J., Masiello, C.A., Hockaday, W.C. and Crowley, D. (2011) Biochar Effects on Soil Biotae-A Review. Soil Biology \& Biochemistry, 43, 1812-1836. https://doi.org/10.1016/j.soilbio.2011.04.022

[33] Sohi, S.P., Krull, E., Lopez-Capel, E. and Bol, R. (2010) A Review of Biochar and Its Use and Function in Soil. Advances in Agronomy, 105, 47-82. https://doi.org/10.1016/S0065-2113(10)05002-9

[34] Liu, Z. and Zhang, F.-S. (2009) Removal of Lead from Water Using Biochars Prepared from Hydrothermal Liquefaction of Biomass. Journal of Hazardous Materials, 167, 933-939. https://doi.org/10.1016/j.jhazmat.2009.01.085

[35] Pellera, F.-M., Giannis, A., Kalderis, D., Anastasiadou, K., Stegmann, R., Wang, J.-Y. and Gidarakos, E. (2012) Adsorption of $\mathrm{Cu}$ (II) Ions from Aqueous Solutions on Biochars Prepared from Agricultural By-Products. Journal of Environmental Management, 96, 35-42. https://doi.org/10.1016/j.jenvman.2011.10.010

[36] Annadurai, G., Juang, R.-S. and Lee, D. (2003) Adsorption of Heavy Metals from Water Using Banana and Orange Peels. Water Science and Technology, 47, 185-190. https://doi.org/10.2166/wst.2003.0049

[37] Lehmann, J., Gaunt, J. and Rondon, M. (2006) Bio-Char Sequestration in Terrestrial Ecosystems-A Review. Mitigation and Adaptation Strategies for Global Change, 11, 403-427. https://doi.org/10.1007/s11027-005-9006-5

[38] Kuzyakov, Y., Bogomolova, I. and Glaser, B. (2014) Biochar Stability in Soil: Decomposition during Eight Years and Transformation as Assessed by CompoundSpecific ${ }^{14}$ C Analysis. Soil Biology and Biochemistry, 70, 229-236. https://doi.org/10.1016/j.soilbio.2013.12.021

[39] Bian, R., Joseph, S., Cui, L., Pan, G., Li, L., Liu, X., Zhang, A., Rutlidge, H., Wong, S. and Chia, C. (2014) A Three-Year Experiment Confirms Continuous Immobilization of Cadmium and Lead in Contaminated Paddy Field with Biochar Amend- 
ment. Journal of Hazardous Materials, 272, 121-128.

https://doi.org/10.1016/j.jhazmat.2014.03.017

[40] Yuan, J.H. and Xu, R.K. (2011) The Amelioration Effects of Low Temperature Biochar Generated from Nine Crop Residues on an Acidic Ultisol. Soil Use and Management, 27, 110-115. https://doi.org/10.1111/j.1475-2743.2010.00317.x

[41] Uchimiya, M., Wartelle, L.H., Klasson, K.T., Fortier, C.A. and Lima, I.M. (2011) Influence of Pyrolysis Temperature on Biochar Property and Function as a Heavy Metal Sorbent in Soil. Journal of Agricultural and Food Chemistry, 59, 2501-2510. https://doi.org/10.1021/jf104206c

[42] Cao, X., Wahbi, A., Ma, L., Li, B. and Yang, Y. (2009) Immobilization of Zn, Cu, and $\mathrm{Pb}$ in Contaminated Soils Using Phosphate Rock and Phosphoric Acid. Journal of Hazardous Materials, 164, 555-564. https://doi.org/10.1016/j.jhazmat.2008.08.034

[43] Harvey, O.R., Herbert, B.E., Rhue, R.D. and Kuo, L.-J. (2011) Metal Interactions at the Biochar-Water Interface: Energetics and Structure-Sorption Relationships Elucidated by Flow Adsorption Microcalorimetry. Environmental Science \& Technology, 45, 5550-5556. https://doi.org/10.1021/es104401h

[44] Kloss, S., Zehetner, F., Dellantonio, A., Hamid, R., Ottner, F., Liedtke, V., Schwanninger, M., Gerzabek, M.H. and Soja, G. (2012) Characterization of Slow Pyrolysis Biochars: Effects of Feedstocks and Pyrolysis Temperature on Biochar Properties. Journal of Environmental Quality, 41, 990-1000. https://doi.org/10.2134/jeq2011.0070

[45] Zhao, L., Cao, X., Mašek, O. and Zimmerman, A. (2013) Heterogeneity of Biochar Properties as a Function of Feedstock Sources and Production Temperatures. Journal of Hazardous Materials, 256-257, 1-9. https://doi.org/10.1016/j.jhazmat.2013.04.015

[46] Ahmad, M., Rajapaksha, A.U., Lim, J.E., Zhang, M., Bolan, N., Mohan, D., Vithanage, M., Lee, S.S. and Ok, Y.S. (2014) Biochar as a Sorbent for Contaminant Management in Soil and Water: A Review. Chemosphere, 99, 19-33. https://doi.org/10.1016/j.chemosphere.2013.10.071

[47] Beesley, L., Moreno-Jiménez, E., Gomez-Eyles, J.L., Harris, E., Robinson, B. and Sizmur, T. (2011) A Review of Biochars' Potential Role in the Remediation, Revegetation and Restoration of Contaminated Soils. Environmental Pollution, 159, 3269-3282. https://doi.org/10.1016/j.envpol.2011.07.023

[48] Rizwan, M., Ali, S., Rizvi, H., Rinklebe, J., Tsang, D.C., Meers, E., Ok, Y.S. and Ishaque, W. (2016) Phytomanagement of Heavy Metals in Contaminated Soils Using Sunflower: A Review. Critical Reviews in Environmental Science and Technology, 46, 1498-1528. https://doi.org/10.1080/10643389.2016.1248199

[49] Whitmore, T. (1984) Tropical Rainforests of the Far East, 2nd Edition, Clarendon Press, Oxford.

[50] Jayasekara, R.D.B. (1970) Horton Plains. Loris, 12, 79-81.

[51] Hendershot, W.H., Lalande, H. and Duquette, M. (2006) Soil Reaction and Exchangable Acidity. In: Soon, Y.K. and Hendershot, W.H., Eds., Soil Sampling and Methods of Analysis, CRC Press; Boca Raton, 141-146.

[52] Kroetsch, D. and Wang, C. (2008) Particle Size Distribution. In: Angers, D.A. and Larney, F.J., Eds., Soil Sampling and Methods of Analysis, CRC Press, Boca Raton, 713-725.

[53] Miller, J.J. and Curtin, D. (2006) Electrical Conductivity and Soluble Ions. In: Schoenau, J.J. and O'Holloran, I.P., Eds., Soil Sampling and Methods of Analysis, CRC Press, Boca Raton, 187-197. 
[54] Simpson, M.J. and Preston, C. (2006) Soil Organic Matter Analysis by Solid-State 13C Nuclear Magnetic Resonance Spectroscopy. In: Gregorich, E.G. and Beare, M.H., Eds., Soil Sampling and Methods of Analysis, CRC Press, Boca Raton, 681-692.

[55] Whitten, M. and Ritchie, G. (1991) Calcium Chloride Extractable Cadmium as an Estimate of Cadmium Uptake by Subterranean Clover. Australian Journal of Soil Research, 29, 215-221. https://doi.org/10.1071/SR9910215

[56] Sauerbeck, D. and Styperek, P. (1985) Evaluation of Chemical Methods for Assessing the $\mathrm{Cd}$ and $\mathrm{Zn}$ Availability from Different Soils and Sources. In: Chemical Methods for Assessing Bio-Available Metals in Sludges and Soils, Elsevier Applied Science, London, 49-67.

[57] Symeonides, C. and McRae, S. (1977) The Assessment of Plant-Available Cadmium in Soils. Journal of Environmental Quality, 6, 120-123. https://doi.org/10.2134/jeq1977.00472425000600020003x

[58] Weil, R. and Brady, N. (2016) Soil Phosphorus and Potassium. In: Weil, R.R. and Brady, N.C., Eds., The Nature and Properties of Soils, 15th Edition, Pearson Education, Upper Saddle River, 643-693.

[59] Osman, K.T. (2013) Physical Properties of Forest Soils. In: Forest Soils. Springer, Cham, 229-251.

[60] Katerji, N., Van Hoorn, J., Hamdy, A. and Mastrorilli, M. (2000) Salt Tolerance Classification of Crops According to Soil Salinity and to Water Stress Day Index. Agricultural Water Management, 43, 99-109.

https://doi.org/10.1016/S0378-3774(99)00048-7

[61] Schrumpf, M., Guggenberger, G., Valarezo, C. and Zech, W. (2001) Tropical Montane Rain Forest Soils. Development and Nutrient Status along Altitudinal Gradient in the South Ecuadorian Andes. Die Erde. Zeitschrift der Gesellschaft für Erdkunde zu Berlin, 132, 43-59.

[62] Hetsch, W. (1976) Standorts-und Vegetationsgliederung in einem tropischen Nebelwald [Location and Vegetation Breakdown in a Tropical Cloud Forest]. Forst Jagdzg, 147, 200-209.

[63] Havlin, J., Hardy, D., Gehl, R. and Spayd, S. (2012) Survey of Nutrient Status in Vitis Vinifera Grapes in North Carolina. Communications in Soil Science and Plant Analysis, 43, 299-314. https://doi.org/10.1080/00103624.2011.638600

[64] Nawaz, R., Parkpian, P., Garivait, H., Anurakpongsatorn, P., DeLaune, R. and Jugsujinda, A. (2012) Impacts of Acid Rain on Base Cations, Aluminum, and Acidity Development in Highly Weathered Soils of Thailand. Communications in Soil Science and Plant Analysis, 43, 1382-1400. https://doi.org/10.1080/00103624.2012.670347

[65] Chin, B.L.F., Yusup, S., Al Shoaibi, A., Kannan, P., Srinivasakannan, C. and Sulaiman, S.A. (2014) Kinetic Studies of Co-Pyrolysis of Rubber Seed Shell with High Density Polyethylene. Energy Conversion and Management, 87, 746-753. https://doi.org/10.1016/j.enconman.2014.07.043

[66] Lindholm-Lehto, P.C. (2019) Biosorption of Heavy Metals by Lignocellulosic Biomass and Chemical Analysis. BioResources, 14, 4952-4995.

[67] McBride, M. (2012) Reactions Controlling Heavy Metal Solubility. In: Stewart, B.A., Ed., Advances in Soil Science, Vol. 10, Springer, New York, 1-56. https://doi.org/10.1007/978-1-4613-8847-0_1

[68] Sposito, G. (2012) Solute Lifetime Correlations in Chemical Transport through 
Field Soils. In: Russo D. and Dagan G., Eds., Water Flow and Solute Transport in Soils, Vol. 20, Springer, Berlin, 82-95. https://doi.org/10.1007/978-3-642-77947-3_7

[69] Gräfe, M., Singh, B. and Balasubramanian, M. (2007) Surface Speciation of Cd (II) and $\mathrm{Pb}$ (II) on Kaolinite by XAFS Spectroscopy. Journal of Colloid and Interface Science, 315, 21-32. https://doi.org/10.1016/j.jcis.2007.05.022

[70] Serrano, S., O’Day, P.A., Vlassopoulos, D., García-González, M.T. and Garrido, F. (2009) A Surface Complexation and Ion Exchange Model of $\mathrm{Pb}$ and Cd Competitive Sorption on Natural Soils. Geochimica et Cosmochimica Acta, 73, 543-558. https://doi.org/10.1016/j.gca.2008.11.018

[71] Loganathan, P., Vigneswaran, S., Kandasamy, J. and Naidu, R. (2012) Cadmium Sorption and Desorption in Soils: A Review. Critical Reviews in Environmental Science and Technology, 42, 489-533. https://doi.org/10.1080/10643389.2010.520234

[72] Gray, C., McLaren, R., Roberts, A. and Condron, L. (1999) Effect of Soil pH on Cadmium Phytoavailability in Some New Zealand Soils. New Zealand Journal of Crop and Horticultural Science, 27, 169-179. https://doi.org/10.1080/01140671.1999.9514093

[73] Degryse, F., Smolders, E. and Parker, D. (2009) Partitioning of Metals (Cd, Co, Cu, $\mathrm{Ni}, \mathrm{Pb}, \mathrm{Zn}$ ) in Soils: Concepts, Methodologies, Prediction and Applications-A Review. European Journal of Soil Science, 60, 590-612. https://doi.org/10.1111/j.1365-2389.2009.01142.x

[74] Park, J.H., Choppala, G.K., Bolan, N.S., Chung, J.W. and Chuasavathi, T. (2011) Biochar Reduces the Bioavailability and Phytotoxicity of Heavy Metals. Plant and Soil, 348, Article No. 439. https://doi.org/10.1007/s11104-011-0948-y

[75] Hartley, W., Riby, P. and Waterson, J. (2016) Effects of Three Different Biochars on Aggregate Stability, Organic Carbon Mobility and Micronutrient Bioavailability. Journal of Environmental Management, 181, 770-778. https://doi.org/10.1016/j.jenvman.2016.07.023

[76] Walker, D.J., Clemente, R. and Bernal, M.P. (2004) Contrasting Effects of Manure and Compost on Soil pH, Heavy Metal Availability and Growth of Chenopodium album L. in a Soil Contaminated by Pyritic Mine Waste. Chemosphere, 57, 215-224. https://doi.org/10.1016/j.chemosphere.2004.05.020

[77] Alvarenga, P., Gonçalves, A., Fernandes, R., De Varennes, A., Vallini, G., Duarte, E. and Cunha-Queda, A. (2009) Organic Residues as Immobilizing Agents in Aided Phytostabilization: (I) Effects on Soil Chemical Characteristics. Chemosphere, 74, 1292-1300. https://doi.org/10.1016/j.chemosphere.2008.11.063 